\title{
Adrenal Rests in the Uro-genital Tract of an Adult Population
}

\author{
Enrico Costantino Falco ${ }^{1} \cdot$ Lorenzo Daniele $^{2} \cdot$ Jasna Metovic $^{3} \cdot$ Enrico Bollito $^{4} \cdot$ Giovanni De Rosa $^{2} \cdot$ Marco Volante $^{5}$. \\ Mauro Papotti ${ }^{3}$
}

Accepted: 28 May 2021 / Published online: 7 June 2021

(c) The Author(s) 2021

\begin{abstract}
Ectopic adrenal rests are a rare condition which can be found in various sites, generally in the retroperitoneum or pelvis along the path of gonadal descent. Their real prevalence is unknown. Males are more commonly affected, at least in the pediatric age. Adrenal rests are usually clinically silent and incidentally found in surgical samples, mostly in the pediatric population, and rarely in adults. With the aim of increasing knowledge and estimating the prevalence of ectopic adrenocortical tissue in the adult population, 44 adrenal rests in the urogenital tract of 40 adults are described. These represent approximately $0.07 \%$ of the total number of urogenital and gynecological surgeries performed in the 22 considered years. Adrenal rests were identified in the spermatic cord (10 males) and in paraovarian, parasalpingeal, or infundibulopelvic ligament locations (30 females). All but one was incidental findings. One case regarded an adrenocortical carcinoma arisen in adrenal rests. A literature review of adrenal ectopia in the urogenital tract of adults identified 57 reported cases from 53 patients, with similar clinicopathological features as those of our series, with the exception of a lower incidence of parasalpingeal locations. Despite their limited clinical implications, awareness of ectopic adrenal rests is essential also in adults for at least two reasons: (a) to correctly identify sources of adrenocortical hormone production in case of adrenal insufficiency or hormonal imbalance and (b) to avoid misinterpretations in the diagnostic workup of renal cell carcinoma, adrenocortical tumors, and rare gonadal neoplasms, including Sertoli/Leydig cell tumors.
\end{abstract}

Keywords Adrenal gland $\cdot$ Ectopia $\cdot$ Adrenal rests $\cdot$ Testis $\cdot$ Ovary $\cdot$ Neoplasia

\section{Introduction}

The adrenal glands develop at 28-30 days after conception from two separate embryological tissues: the medulla derived from neural crest in proximity of dorsal aorta and the cortex from the intermediate mesoderm in the region between the genital ridge and the root of the mesentery [1]. During the 7 th week, fusion between the two components

Marco Volante

marco.volante@unito.it

1 Pathology Unit, Department of Medical Sciences, Città Della Salute E Della Scienza Hospital, University of Turin, Turin, Italy

2 Pathology Unit, Mauriziano Hospital, Turin, Italy

3 Pathology Unit, Department of Oncology, Città Della Salute E Della Scienza Hospital, University of Turin, Turin, Italy

4 Pathology Unit, San Luigi Hospital, Orbassano, Turin, Italy

5 Pathology Unit, Department of Oncology at San Luigi Hospital, University of Turin, Orbassano, Turin, Italy takes place by migration and penetration of neural crest cells into the unencapsulated cortex [2]. At birth, the fetal cortex forms the largest part (70-85\%) of the adrenal cortex, but it quickly undergoes vascular engorgement and atrophy. At the same time, the outer permanent cortex begins to differentiate into the definitive three layers [3-5].

Adrenal ectopia is defined as the presence of adrenal tissue in a location other than the adrenal glands, including the region around the adrenal gland, the celiac plexus, the kidney, and the route of gonadal descent, comprising also hernia sacs [6-10]. In exceptional cases, it can also be found in bizarre sites, such as placenta [11], lung [12], or intracranial cavity [13].

Ectopic adrenal nodules probably originate either from multiple primordia or from secondarily detached cortical fragments during the penetration of medullary cells into cortical anlage [14, 15]. Subsequently, these rests may remain close to the main gland or migrate, mostly in the pelvis or the groin region. The most frequent pelvic or groin location can be explained by the fact that the fetal 
adrenal cortex is often unencapsulated and develops in close contact with the gonads.

Ectopic nodules usually contain cortical components, only [5]. However, in the area of the celiac plexus, ectopic adrenal nodules have been reported to contain both cortex and medulla in about $50 \%$ of cases [16]. Ectopia in unusual anatomic sites is more difficult to explain, and other theories have been proposed, including a possible origin from pluripotent cells [14].

Macroscopically, ectopic adrenal tissue looks like a round, yellow, and well-defined node, usually smaller than $1 \mathrm{~cm}$. Ectopic cortex shows normal morphology with the typical zonation, and responds to physiological ACTH stimulation. Therefore, although these rests are usually clinically silent, they may undergo hyperplasia in conditions associated with excessive adrenocorticotropic hormone (ACTH) production, such as in patients with Cushing's disease or Nelson's syndrome following bilateral adrenalectomy [17]. Ectopic adrenal nodules could also give rise to malignant tumors. Moreover, in congenital adrenal hyperplasia (CAH), an autosomal recessive disease that causes adrenal cortical dysfunction, the increased ACTH levels induce adrenocortical hyperplasia of orthotopic and heterotopic adrenal tissue [18].

The real incidence of adrenal rests is unknown, but they are reported to be much more frequent in infants than in adults. In intrauterine life, the adrenal glands are proportionally 20 times larger than those in adulthood, so ectopic tissue is also likely larger and more readily identified in infants and children. In fact, they are found in about 50\% of newborns near the adrenal gland and in $7.5-15 \%$ of cases in the inguinal region, while their incidence drops to $1 \%$ in adults, as they are believed to degenerate or undergo atrophy within a few years $[10,14,15]$.

The majority of ectopic adrenal tissues are described as incidental findings during surgical procedures in the urogenital tract of male children. Moreover, they are identified mostly by the pathologist in surgical material, whereas $14 \%$ of cases, only, are discovered by the surgeon, due to their small size and fat-like appearance [10]. In the adult population, adrenal ectopia is a rare occurrence.

Both in pediatric and in adult patients, the presence of ectopic adrenal tissue in the inguinal region is associated with undescended testis, probably because of a thorough dissection and careful examination of the spermatic cord. However, an alternative hypothesis suggest that inadequate or late migration of primordial germ cells could lead to closer interactions with adrenal cortical cells affecting the right location [19, 20].

Based on the above, the aim of the present study was to review a large retrospective series of adrenal ectopia in the urogenital tract in adults.

\section{Materials and Methods}

We retrospectively collected all cases of adrenal ectopia in the urogenital tract close to the gonads detected in surgically resected specimens of adult patients (age > 18 years) between 1999 and 2020 in three academic hospitals of Torino, Italy (Mauriziano, San Luigi and Città della Salute e della Scienza University Hospitals). In the considered timeframe, 53,983 urogenital and gynecological surgical specimens were submitted to histopathological examination. In particular, 39,286 and 14,697 surgical procedures were performed in women and in men, respectively. Histological reports were retrieved from the pathological databases of the three pathology divisions and were then integrated with data from the clinical and surgical databases. Data about sex, age, relevant medical history, reason for surgery, location, and morphological features of the ectopic rests were recorded. The study was approved by the Institutional Review Board of the San Luigi Hospital (Protocol AMPRECCO, No. 128/2010). After anonymization of pathology slides and blocks by a pathology staff member not involved in this study, all specimens were reviewed to confirm the diagnosis of ectopic adrenal tissue and to evaluate the specific histopathological features. In some cases, immunohistochemical stains for Melan-A/MART-1 (clone A103, Benchmark AutoStainer Ventana Medical Systems, AZ, USA) and for alpha-inhibin (clone R1, Ventana) were performed using a Ventana Roche immunohistochemistry platform (Fig. 1).

Moreover, the previous literature was reviewed to compare the morphological features of adrenal ectopia in the urogenital tract of the adult population. A search was set up in the PubMed database using the terms "ectopic adrenal," "accessory adrenal," "adrenal heterotopia," "adrenal rests," browsing titles, and abstracts in English language. All the articles reporting well-documented cases in adult patients (age $>18$ years) and localized in the urogenital region near the gonads were included.

\section{Results}

Forty cases of ectopic adrenal nodules in the urogenital region adjacent to the gonads were collected and reviewed. One case (No. 9) had already been described as part of a single case report of a testicular seminoma associated to adrenal rests [21], and case No. 14 was a consultation case reviewed by one of us (EB) (Fig. 2). 
Fig. 1 Case 15-Adrenal ectopia in the spermatic cord (original magnification $\times 50$ ). Hematoxylin and eosin staining shows a well-defined nodule composed of cortical cells only and with a thin capsule in the adipose tissue close to the epididymis (a). Melan-A/MART-1 reactivity supported the diagnosis of an adrenal rest (b)
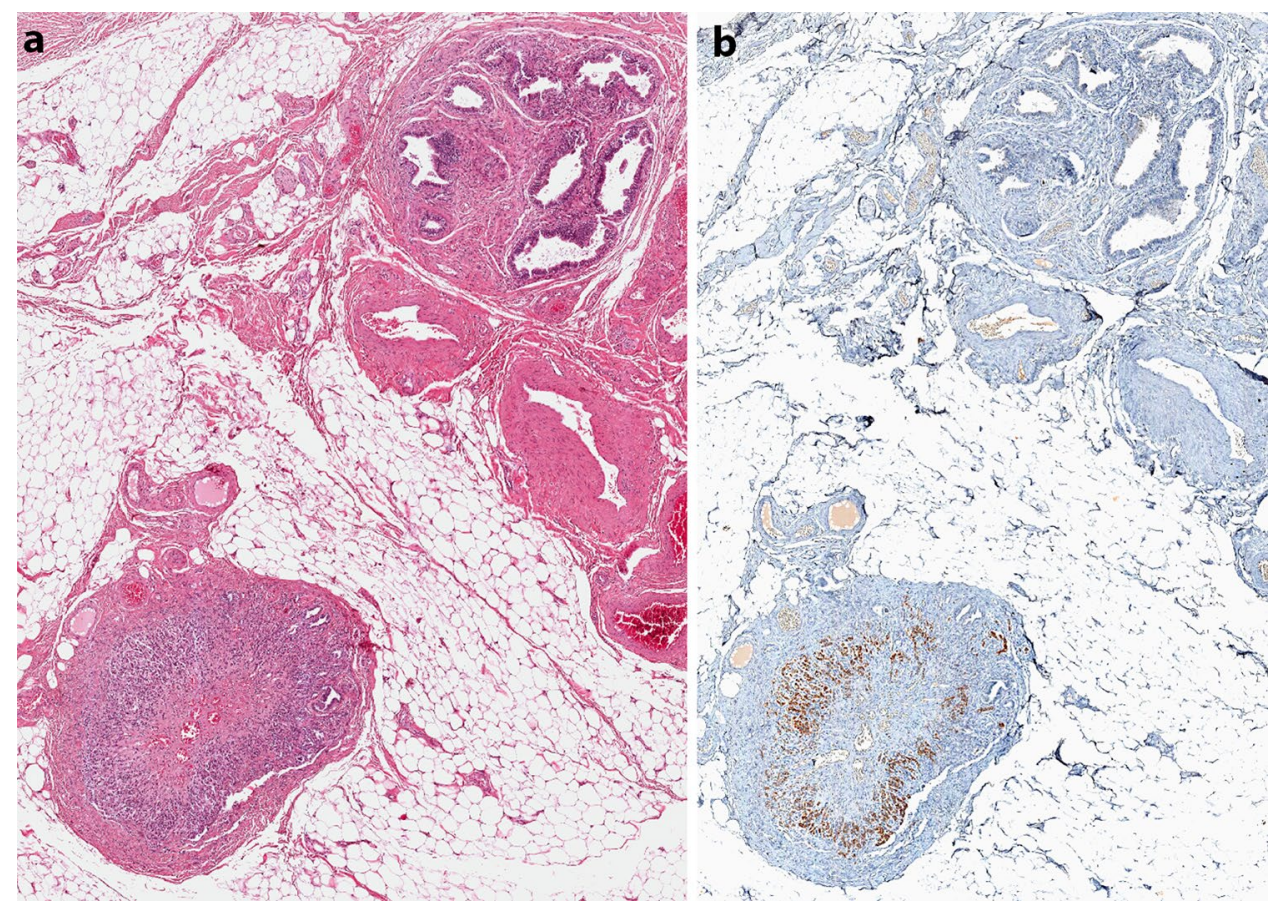

\section{General Information and Clinical Findings}

Overall, adrenal rests were detected in $0.07 \%$ of urogenital tract surgical specimens in adults. The clinicopathological results are summarized in Table 1. Ectopic rests were found in $10(25 \%)$ men and 30 women (75\%), with a mean age of 54.6 years (range 26-86). Females had a mean age of 57.2 years, while males of 45.9 years. The nodules had a mean size of $3.0 \mathrm{~mm}(1-8 \mathrm{~mm})$. In 37 patients, a single adrenal rest was identified, whereas multiple small nodules were found in three women, either in the adipose tissue close to the ovaries or in the infundibulopelvic ligament. The nodules were almost equally distributed on the right and left side (20 and 19, respectively; in one case, the information was missing), but with a difference between sexes. Indeed, a right-side preference was observed in men $(6 / 9,66.7 \%$; missing information in one case), but not in women $(14 / 30,46.7 \%)$.

All but one case was clinically silent, and none of them was recognized by surgeons during excision: in three cases, ectopic nodules were incidentally discovered at the time of macroscopic dissection in the pathology laboratory, while most of them were recognized at the time of microscopic analysis, only. None of the patients had primary adrenal diseases or symptoms related to hormonal excess, and no hormonal deficits resulted from the excision of the accessory tissue. Among males, the ectopic nodules were found in the spermatic cord after surgery performed for hernia
Fig. 2 Case 40-Parasalpingeal adrenal rest stained with hematoxylin and eosin (original magnification $\times 50$ ). A $2 \mathrm{~mm}$ adrenocortical nodule is located in the vascularized and loose connective tissue surrounding the salpinx

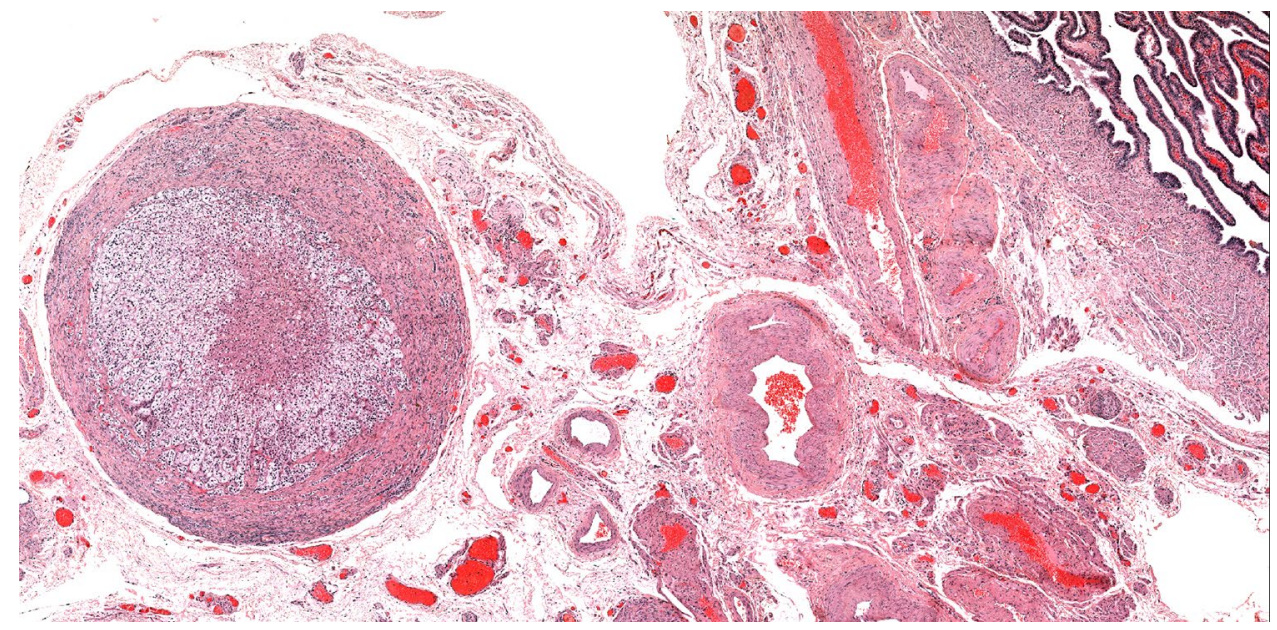


Table 1 Clinicopathological features of the 44 reported adrenal rests in the urogenital tract of 40 adults

\begin{tabular}{|c|c|c|c|c|c|c|}
\hline \multirow[t]{2}{*}{ No } & \multirow[t]{2}{*}{ Sex/Age } & \multirow[t]{2}{*}{ Cause of surgery } & \multicolumn{4}{|l|}{ Adrenal rests } \\
\hline & & & Laterality/Location & $\begin{array}{l}\text { Macro/ } \\
\text { microscopic } \\
\text { finding }\end{array}$ & Size $(\mathrm{mm})$ & Histology \\
\hline 1 & $\mathrm{M} / 48$ & Cryptorchidism in single congenital kidney & L/Spermatic cord & Micro & 4 & Normal cortex \\
\hline 2 & $\mathrm{~F} / 49$ & Uterine leiomyomas & NA/Parasalpingeal tissue & Micro & 2 & Normal cortex \\
\hline 3 & $\mathrm{~F} / 75$ & Endometrial carcinoma & $\mathrm{L} /$ Paraovarian tissue & Micro & 1 & Normal cortex \\
\hline 4 & $\mathrm{~F} / 65$ & Endometrial carcinoma & L/Parasalpingeal tissue & Micro & 2 & Normal cortex \\
\hline 5 & $\mathrm{~F} / 46$ & Endometriotic cyst & NA/Parasalpingeal tissue & Micro & 3 & Normal cortex \\
\hline 6 & $\mathrm{~F} / 68$ & Uterine prolapse & 1R-2L/Paraovarian tissue & Micro & $1 / 2 / 2$ & 3 nodules, normal cortex \\
\hline 7 & $\mathrm{~F} / 47$ & Prophylactic adnexectomy & $\mathrm{R} /$ Paraovarian tissue & Micro & 3 & Normal cortex \\
\hline 8 & $\mathrm{M} / 56$ & Inguinal hernia and cryptorchidism & $\mathrm{R} /$ Spermatic cord & Micro & 3 & Normal cortex \\
\hline 9 & $\mathrm{M} / 43$ & Seminoma & $\mathrm{R} /$ Spermatic cord & Macro & 3 & Normal cortex \\
\hline 10 & $F / 32$ & Ovarian cystadenoma & $\mathrm{R} /$ Ovarian hilus & Micro & 2 & Normal cortex \\
\hline 11 & $\mathrm{M} / 37$ & Mixed malignant germ cells tumor & $\mathrm{R} / \mathrm{Spermatic}$ cord & Micro & 1 & Normal cortex \\
\hline 12 & $\mathrm{M} / 28$ & Mixed malignant germ cells tumor & $\mathrm{R} /$ Spermatic cord & Macro & 3 & Normal cortex \\
\hline 13 & $\mathrm{~F} / 52$ & Ovarian cystadenofibroma & L/Paraovarian tissue & Micro & 2 & Normal cortex \\
\hline 14 & $\mathrm{M} / \mathrm{NA}$ & Inguinal mass & NA/ Spermatic cord & Macro & NA & Carcinoma \\
\hline 15 & $\mathrm{M} / 29$ & Seminoma & L/Spermatic cord & Micro & 2 & Normal cortex \\
\hline 16 & $\mathrm{M} / 26$ & Mixed malignant germ cells tumor & $\mathrm{R} /$ Spermatic cord & Micro & 4 & Normal cortex \\
\hline 17 & $\mathrm{~F} / 60$ & Pelvic leiomyosarcoma & NA/Paraovarian tissue & Micro & 5 & Normal cortex \\
\hline 18 & $\mathrm{~F} / 50$ & Endometrial stromal sarcoma & L/Parasalpingeal tissue & Micro & 8 & Normal cortex \\
\hline 19 & $\mathrm{~F} / 55$ & Ovarian carcinoma & Peritoneum L/paracolic gutter & Micro & 3 & Normal cortex \\
\hline 20 & $\mathrm{~F} / 67$ & Salpingeal adenocarcinoma & $\mathrm{R} /$ Infundibulopelvic ligament & Micro & 4 & Normal cortex \\
\hline 21 & $\mathrm{~F} / 61$ & Endometrial carcinoma & $\mathrm{R} /$ Infundibulopelvic ligament & Micro & $3 / 5$ & 2 nodules, normal cortex \\
\hline 22 & $\mathrm{~F} / 71$ & Bladder urothelial carcinoma & $\mathrm{L} /$ Paraovarian tissue & Micro & 4 & Normal cortex \\
\hline 23 & $\mathrm{~F} / 85$ & Ovarian borderline cystadenoma & NA/Parasalpingeal tissue & Micro & 5 & Normal cortex \\
\hline 24 & $\mathrm{~F} / 55$ & Vaginal carcinoma & $\mathrm{R} /$ Parasalpingeal tissue & Micro & 3 & Normal cortex \\
\hline 25 & $\mathrm{~F} / 52$ & Ovarian carcinoma & $\mathrm{R} /$ Infundibulopelvic ligament & Micro & $2 / 2$ & 2 nodules, normal cortex \\
\hline 26 & $\mathrm{~F} / 54$ & Endometrial carcinoma & L/Parasalpingeal tissue & Micro & 3 & Normal cortex \\
\hline 27 & $\mathrm{~F} / 54$ & Endometriotic cyst & $\mathrm{R} /$ Parasalpingeal tissue & Micro & 2 & Normal cortex \\
\hline 28 & $\mathrm{~F} / 56$ & Ovarian cystadenoma & L/Ovarian hilus & Micro & 2 & Normal cortex \\
\hline 29 & $\mathrm{~F} / 75$ & Endometrial carcinoma & L/Infundibulopelvic ligament & Micro & 1 & Normal cortex \\
\hline 30 & $\mathrm{~F} / 51$ & Adult granulosa cell tumor & L/Parasalpingeal tissue & Micro & 2 & Normal cortex \\
\hline 31 & $\mathrm{~F} / 86$ & Bladder urothelial carcinoma & $\mathrm{R} /$ Parasalpingeal tissue & Micro & 3 & Normal cortex \\
\hline 32 & $\mathrm{~F} / 60$ & Ovarian cystadenoma & $\mathrm{R} /$ Parasalpingeal tissue & Micro & 1 & Normal cortex \\
\hline 33 & $\mathrm{~F} / 41$ & Cervical adenocarcinoma & $\mathrm{R} /$ Parasalpingeal tissue & Micro & 3 & Normal cortex \\
\hline 34 & $\mathrm{M} / 80$ & Spermatocytic tumor & L/Parafunicular fat & Micro & 3 & Normal cortex \\
\hline 35 & $\mathrm{~F} / 57$ & Endometrial carcinoma & L/Parasalpingeal tissue & Micro & 4 & Normal cortex \\
\hline 36 & $\mathrm{M} / 66$ & Prostate adenocarcinoma & $\mathrm{R} /$ Parafunicular fat & Micro & 5 & Normal cortex \\
\hline 37 & $\mathrm{~F} / 46$ & Salpingitis & L/Parasalpingeal tissue & Macro & 6 & Normal cortex \\
\hline 38 & $\mathrm{~F} / 39$ & Salpingo-ovarian abscess & $\mathrm{L} /$ Paraovarian tissue & Micro & 4 & Normal cortex \\
\hline 39 & $\mathrm{~F} / 60$ & Metastatic gastric carcinoma & $\mathrm{R} /$ Parasalpingeal tissue & Micro & 2 & Normal cortex \\
\hline 40 & $\mathrm{~F} / 48$ & Uterine leiomyomas & L/Parasalpingeal tissue & Micro & 2 & Normal cortex \\
\hline
\end{tabular}

$F$ female, $M$ male, $R$ right, $L$ left, $N A$ not available

repair, prostate carcinoma, cryptorchidism, or testicular tumors, while in females, they were discovered in paraovarian or paratubal location after surgery for gynecological neoplasms or bladder carcinoma. Case No. 14 was a carcinoma strictly related to adrenal rests identified in the periphery of the tumor and close to the testis. The patient underwent surgery for inguinal pain, and multiple nodules were found along the spermatic cord. A hepatic node was 
also excised, whereas no abnormalities were detected in the adrenal glands. Benign rests in males were associated with testicular malignancy (six cases), prostate adenocarcinoma (one case), and with undescended testis (the remaining two cases). Interestingly, in one of such cases (\#1), cryptorchidism was associated with a congenital solitary kidney, ipsilateral to the cryptorchid testis. Among females, fourteen cases were associated with gynecological malignancies (two leiomyosarcomas, six endometrial, four ovarian/salpingeal, one cervical, and one vaginal carcinomas), three cases with extra-gynecological malignancies (two bladder and one gastric carcinomas), and one borderline ovarian tumor. The other twelve cases were associated with benign gynecological conditions including four ovarian cystadenomas, two leiomyomas, two endometriotic cysts, two salpingitis, and one uterine prolapse, the remaining case being a prophylactic bilateral adnexectomy in a BRCA mutated breast carcinoma patient.

\section{Pathological Findings}

Macroscopically, adrenal rests presented as circumscribed round to oval small nodules, with a tan-yellow color, and different in consistency from the surrounding adipose tissue. The microscopic analysis revealed well-defined nodules composed of adrenal cortex, only, surrounded by a thin fibrous capsule. They had all a comparable morphology, with cells arranged in two or three layers. Zona fasciculata was predominant in all cases, followed by zona reticularis. Glomerulosa cells were present in small clusters beneath the capsule in larger nodules and absent in smaller ones. The cells had a cord-like arrangement with a minimal interposed stroma, and were large and polygonal, with abundant vacuolated granular and eosinophilic cytoplasm and small nuclei. Conversely, in both testicular and hepatic lesions of case No. 14, a solid proliferation of moderately atypical polygonal cells with a high mitotic count and foci of necrosis was identified. A diagnosis of adrenocortical carcinoma in ectopic adrenal rests with liver metastasis was rendered in this case. In addition to the routine hematoxylin and eosin, immunostaining for Melan-A (in case 11, 15, 16, 29, and 30) and for alpha-inhibin (in case 13) were also performed, confirming the adrenocortical nature of the tissue. Notably, all cases in our series were correctly identified in the original diagnosis as ectopic adrenal cortical tissue, irrespective of the location and pathology associated.

\section{Review of the Literature}

The English literature review identified 37 articles reporting 57 ectopic adrenal nodules in the urogenital tract (excluding the kidney) of 53 adult patients ( 27 men and 26 women). Demographic and clinic-pathological data are summarized in Table 2. Almost all studies are single-case reports (33/37 papers), with the largest series being those by Falls and Gutowski (11 and 5 cases, respectively) $[6,16]$. The mean age was 41.8 years (range 19-78 years). Females had a mean age of 38.2 years, while males of 45.5 years. The nodules had a mean size of $15 \mathrm{~mm}$ (range $0.4-145 \mathrm{~mm}$ ). In 3 patients ( 2 females and 1 male), bilateral nodules were found, while two ectopic rests were located in the same hernia sac in a man. In the other 49 patients, a single adrenal rest was identified. Overall, the majority of nodules were identified on the right side (36/56, 64.3\%; the information was not available in one case). Among men, ectopic tissue was found in the spermatic cord, in hernia sacs, and in paratesticular location. In women, the most frequent locations were the broad ligament and the paraovarian region, followed by the wall of ovarian cysts and a single case in the appendiceal tissue adherent to mesovarium. Only the nodule found in the wall of an ovarian serous cystadenoma had both adrenal cortical and medullary components, while in all the other cases, in both males and females, adrenal cortical tissue, only, was identified. The majority of cases were asymptomatic and incidentally found after surgical exploration of the pelvic region for different reasons. Of the 54 cases with this information available, 42 were recognized at the time of surgical excision or during the macroscopic gross evaluation of the specimen and 12 were identified at the microscopic analysis. Nine cases were associated to an adrenocortical tumor, namely, six clinically silent adenomas and three carcinomas with Cushing's syndrome.

\section{Discussion}

In this study, we reported a series of 44 adrenal rests found in the peri-gonadal location of the urogenital tract in an adult population of 40 patients, with a female predominance. A PubMed review of the English literature disclosed 57 published cases, for a total of 101 ectopic adrenal nodules in the path of gonadal descent, supporting the notion that adrenal ectopia is a rare, but not exceptional, occurrence in adults.

After birth, this accessory tissue undergoes involution, and in the presence of a normal hormonal function of the main glands, the ectopic nodes are believed to undergo complete atrophy and eventually disappear [14]. During the atrophic process, small adrenal rests are relatively common in the pediatric age, especially in male children undergoing urogenital surgery or hernia repair, often in the presence of congenital adrenal hyperplasia.

In adults, small adrenal rests may occasionally remain close to urogenital tract organs, and in exceptional conditions of hormonal deficits or abnormal stimulation, they could increase in size and become the source of adrenocortical hormone production. Adrenal rests are usually identified 
Table 2 Clinicopathological features of 57 adrenal rests reported in literature in the urogenital tract of 53 adults

\begin{tabular}{|c|c|c|c|c|c|c|c|}
\hline \multirow[t]{2}{*}{ No } & \multirow[t]{2}{*}{ Author [reference] } & \multirow[t]{2}{*}{ Sex/Age } & \multirow[t]{2}{*}{ Cause of surgery } & \multicolumn{4}{|l|}{ Adrenal rests } \\
\hline & & & & Laterality/Location & $\begin{array}{l}\text { Macroscopic/ } \\
\text { microscopic } \\
\text { finding }\end{array}$ & Size $(\mathrm{mm})$ & Histology \\
\hline 1 & Gualtieri [22] & $\mathrm{M} / 31$ & Scrotal mass & L/Spermatic cord & Macro & 40 & Adenoma \\
\hline 2 & Janovski [23] & $\mathrm{F} / 42$ & Cervical carcinoma & R/Mesosalpinx & Macro & 15 & Choristoma \\
\hline 3 & Schechter [14] & $\mathrm{M} / 19$ & Inguinal hernia & L/Hernia sac & Macro & 2 & Normal cortex \\
\hline 4 & Morimoto [24] & $\mathrm{M} / 57$ & $\begin{array}{l}\text { Scrotal mass in } \\
\text { Cushing's syndrome }\end{array}$ & L/Paratesticular & Macro & 50 & Carcinoma \\
\hline 5 & Gutowski [6] & $\mathrm{M} / 58$ & Inguinal hernia & R/Hernia sac & Micro & 4 & Normal cortex \\
\hline 6 & Gutowski [6] & M/66 & Inguinal hernia & $\mathrm{R} /$ Hernia sac & Macro & 10 & Normal cortex \\
\hline 7 & Gutowski [6] & $\mathrm{M} / 44$ & Inguinal hernia & $\mathrm{R} /$ Hernia sac & Macro & $2 / 5$ & 2 nodules, normal cortex \\
\hline 8 & Gutowski [6] & $\mathrm{M} / 45$ & Inguinal hernia & L/Hernia sac & Macro & 3 & Normal cortex \\
\hline 9 & Gutowski [6] & $\mathrm{M} / 34$ & Inguinal hernia & $\mathrm{R} /$ Hernia sac & Micro & 2 & Normal cortex \\
\hline 10 & Anderson [15] & $\mathrm{F} / 62$ & Acute appendicitis & $\begin{array}{l}\mathrm{R} / \text { Appendiceal } \\
\text { mesentery }\end{array}$ & Macro & 10 & Normal cortex \\
\hline 11 & Anderson [15] & $\mathrm{M} / 53$ & Inguinal mass & $\mathrm{R} /$ Spermatic cord & Macro & 10 & Normal cortex \\
\hline 12 & Lodeville [25] & $\mathrm{M} / 21$ & $\begin{array}{l}\text { Nodule of the spermatic } \\
\text { cord }\end{array}$ & R/Spermatic cord & Macro & 1.5 & Normal cortex \\
\hline 13 & Czaplicki [26] & $\mathrm{M} / 34$ & $\begin{array}{l}\text { Cryptorchidism and } \\
\text { sterility }\end{array}$ & $\mathrm{R} /$ Paratesticular & Macro & 5 & Adenoma \\
\hline 14 & Czaplicki [26] & $\mathrm{M} / 34$ & $\begin{array}{l}\text { Cryptorchidism and } \\
\text { sterility }\end{array}$ & L/Paratesticular & Micro & NA & Normal cortex \\
\hline 15 & Van Ingen [27] & $\mathrm{F} / 41$ & $\begin{array}{l}\text { Testosterone-producing } \\
\text { tumor }\end{array}$ & L/Mesovarium & Macro & 40 & Adenoma \\
\hline 16 & Sasano [28] & $\mathrm{F} / 43$ & Uterine leiomyoma & $\mathrm{R} /$ Broad ligament & Macro & 50 & Adenoma \\
\hline 17 & Ventura [29] & $\mathrm{M} / 42$ & Scrotal trauma & R/Spermatic cord & Macro & 5 & Normal cortex \\
\hline 18 & Mari [21] & $\mathrm{M} / 43$ & Seminoma & $\mathrm{R} /$ Spermatic cord & Macro & 3 & Normal cortex \\
\hline 19 & Usta [30] & $\mathrm{F} / 21$ & Ovarian cystadenoma & L/Ovary & Macro & 2 & $\begin{array}{l}\text { Normal cortex and } \\
\text { medulla }\end{array}$ \\
\hline 20 & Iyengar [8] & $\mathrm{M} / 54$ & Inguinal hernia & R/Hernia sac & Micro & 0.4 & Normal cortex \\
\hline 21 & Ors [31] & $\mathrm{F} / 44$ & Paraovarian mass & $\mathrm{R} /$ Paraovarian & Macro & 20 & Adenoma \\
\hline 22 & Jain [32] & $\mathrm{M} / 65$ & $\begin{array}{l}\text { Testicular masses in } \\
\text { Cushing's syndrome }\end{array}$ & R-L/Paratesticular & Macro & $31 / 85$ & 2 nodules, carcinoma \\
\hline 23 & El Demellawy [7] & $\mathrm{M} / 78$ & Inguinal hernia & L/Hernia sac & Macro & 7 & Normal cortex \\
\hline 24 & Yasar [33] & $\mathrm{F} / 50$ & Granulosa cell tumor & L/Ovary & NA & NA & Normal cortex \\
\hline 25 & Rabie [34] & $\mathrm{M} / 26$ & Undescended testis & L/Paratesticular & Micro & NA & Normal cortex \\
\hline 26 & Zhong [35] & $\mathrm{F} / 56$ & Ovarian cystadenoma & $\mathrm{R} /$ Paraovaric & Micro & 2 & Normal cortex \\
\hline 27 & Müllhaupt [36] & $\mathrm{M} / 44$ & Varicocele & NA/Spermatic cord & Macro & 9 & Normal cortex \\
\hline 28 & Floyd [37] & $\mathrm{M} / 45$ & $\begin{array}{l}\text { Seminoma in } \\
\text { undescended testis }\end{array}$ & $\mathrm{R} / \mathrm{Spermatic}$ cord & Macro & 5 & Normal cortex \\
\hline 29 & Takeuchi [38] & $\mathrm{M} / 52$ & $\begin{array}{l}\text { Lipoma of spermatic } \\
\text { cord }\end{array}$ & $\mathrm{R} / \mathrm{Spermatic}$ cord & Micro & NA & Normal cortex \\
\hline 30 & Kasajima [39] & $\mathrm{F} / 29$ & $\begin{array}{l}\text { Pelvic mass in } \\
\text { oligomenorrhea }\end{array}$ & L/Broad ligament & Macro & 65 & Adenoma \\
\hline 31 & Niveditha [40] & $\mathrm{M} / 64$ & Inguinal hernia & $\mathrm{R} /$ Hernia sac & Macro & 4 & Normal cortex \\
\hline 32 & Raman [41] & $\mathrm{M} / 28$ & Undescended testis & $\mathrm{R} /$ Paratesticular & Micro & 2 & Normal cortex \\
\hline 33 & Sangeeta [42] & $\mathrm{M} / 21$ & Undescended testis & $\mathrm{R} /$ Paratesticular & Macro & NA & Normal cortex \\
\hline 34 & Khandakar [43] & $\mathrm{F} / 26$ & Ovarian cystadenoma & $\mathrm{R} /$ Paratubal & Micro & 6 & Normal cortex \\
\hline 35 & Chentli [44] & $\mathrm{F} / 34$ & $\begin{array}{l}\text { Pelvic mass in } \\
\text { Cushing's syndrome }\end{array}$ & R/Ovary & Macro & 145 & Carcinoma \\
\hline 36 & Senescende [10] & $\mathrm{M} / 44$ & Inguinal hernia & $\mathrm{R} /$ Hernia sac & Macro & 10 & Normal cortex \\
\hline
\end{tabular}


Table 2 (continued)

\begin{tabular}{|c|c|c|c|c|c|c|c|}
\hline \multirow[t]{2}{*}{ No } & \multirow[t]{2}{*}{ Author [reference] } & \multirow[t]{2}{*}{ Sex/Age } & \multirow[t]{2}{*}{ Cause of surgery } & \multicolumn{4}{|l|}{ Adrenal rests } \\
\hline & & & & Laterality/Location & $\begin{array}{l}\text { Macroscopic/ } \\
\text { microscopic } \\
\text { finding }\end{array}$ & Size $(\mathrm{mm})$ & Histology \\
\hline 37 & Billone [45] & $\mathrm{F} / 22$ & $\begin{array}{l}\text { R/hydrosalpinx and } \\
\text { torsion }\end{array}$ & $\begin{array}{l}\text { L/Infundibulopelvic } \\
\text { ligament }\end{array}$ & Macro & 3 & Normal cortex \\
\hline 38 & Chew [46] & $\mathrm{F} / 22$ & Ovarian cystadenoma & L/Ovary & Micro & NA & Normal cortex \\
\hline 39 & Kassaby [47] & $\mathrm{M} / 56$ & Inguinal hernia & L/Hernia sac & Micro & 1.5 & Normal cortex \\
\hline 40 & Sahin [48] & $\mathrm{F} / 65$ & Ovarian cystadenoma & L/Ovary & NA & NA & Normal cortex \\
\hline 41 & Tingi [49] & $\mathrm{F} / 48$ & Dysmenorrhea & L/Fallopian tube & NA & NA & Normal cortex \\
\hline 42 & Alimoradi [50] & $\mathrm{M} / 37$ & $\begin{array}{l}\text { Bilateral inguinal } \\
\text { hernia }\end{array}$ & R/Hernial sac & Micro & NA & Normal cortex \\
\hline 43 & $\begin{array}{l}\text { Falls [16] } 13 \text { cases } \\
\text { in } 11 \text { consecutive } \\
\text { pts }\end{array}$ & $\mathrm{F} / 35.7$ & $\begin{array}{l}\text { Endometrial carcinoma, } \\
\text { leiomyomas, } \\
\text { polycystic ovaries, } \\
\text { ruptured tubal }\end{array}$ & $\begin{array}{l}\text { 8R, 1L, } 2 \text { Bilateral/ } \\
\text { Broad ligament }\end{array}$ & Macro & $2(1-4)$ & Normal cortex \\
\hline
\end{tabular}

$F$ female, $M$ male, $R$ right, $L$ left, $N A$ not available, pts patients

in specimens of gynecological surgery or in the context of inguinal hernia repair or orchidopexy procedures $[14,26$, 34]. In the present case series, undescended testis in male patients was the unique non-neoplastic associated pathology, with 2 out of 10 cases. Interestingly, the association of adrenal ectopia with cryptorchidism and ipsilateral congenital solitary kidney in case \#1 highlights the embryological relationship between fetal adrenal and genitourinary structures. Renal agenesis is reported to be associated with absence or ectopia of adrenal gland in about $10 \%$ of cases [51], and cryptorchidism could be associated with minor or major urinary tract abnormalities such as single kidney, unilateral renal hypoplasia, ureterocele, or ureteric stenosis, usually ipsilateral to the undescended testis [52]. However, in our case, the urological anomaly was contralateral to the cryptorchid testis (left undescended testis and right kidney agenesis). No other cases of ectopic adrenal tissue associated with undescended testis and concomitant renal agenesis have been described in adults, so far. One case in a man was a primary adrenocortical carcinoma from ectopic adrenal tissue in the spermatic cord, associated with liver metastases. A literature search revealed only three previous cases of carcinoma arising in ectopic adrenal rests of the urogenital tract in the adult population, all associated with Cushing's syndrome [24, 32, 44]. The remaining seven male patients were affected by testicular (six cases) or prostatic (one case) malignancies. To the best of our knowledge, only three cases associated with testicular tumors in adults are on record in the English literature [21, 25, 37].

In female patients, the majority of surgical specimens derived from hysterectomies or ovariectomies, with a remarkable finding of adrenal rests in ovarian and salpingeal ligaments ( 9 and 16 cases, respectively), the remaining cases being located in the infundibulopelvic ligament or paracolic tissue.

In our adult series of adrenal ectopia, the sex distribution and overall anatomical sites, including the absence of a predominant right location, are opposed to those of the literature. A possible explanation could be that in the pediatric population, surgical procedures more frequently are performed in males and involve the groin region, leading to a higher detection of clinically silent adrenal rests along the spermatic cord or rete testis [10, 19, 53, 54]. Indeed, in adults, gonadal resection is more likely to occur in women, thus explaining the higher number of adrenal rests in female patients of the current series. However, if we compare the number of ectopic nodules with the number of surgical procedures performed in the same time interval, we get the same incidence rate $(0.07 \%)$ in both sexes. A very old study on a consecutive series of hysterectomies showed that an extensive sampling of the broad ligaments allowed to identify adrenal rests (having a median size of $2 \mathrm{~mm}$ ) in up to $25 \%$ of cases [16]. Therefore, the evaluation of the exact incidence and sex distribution of adrenal rests in the general population and in adults in particular, seems to suffer from numerous biases, precluding a precise estimate.

Regarding right-side predominance of adrenal ectopia, this is well documented in the male pediatric population, but not in adults, due to the lack of large series [10, 19]. Considering the currently reported cases, the right-side preferential location seems to occur also in adults, especially in male patients, being negligible in females. In any case, a selection bias linked to the type of pathology specimens analyzed cannot be excluded: in fact, inguinal hernias are the main reason for groin region exploration in children and they typically develop far more commonly 
on the right side than in the left [55]. Moreover, also cryptorchidism and testicular cancer are reported to have a right-side predominance and, therefore, adrenal rests may well be incidentally detected in the same location [56].

Adrenal medulla was not found in any of the cases of the current series and only in one case among those described in the literature, with an overall prevalence of $1 \%(1 / 101)$. This finding contrasts with the data of some early literature that reported the presence of medulla in up to $50 \%$ of cases of adrenal rests in the celiac-plexus area [16]. This discordance may be explained by a different time of adrenal tissue displacement, with the nodules in the celiac-plexus area, localized close to the adrenal glands, arising in a late phase of embryonic development (after the fusion between cortex and medulla), while those found far away being displaced at early (pre-fusion) stages.

Regarding hormonal function of adrenal rests, although such ectopic tissue is generally devoid of clinical relevance, it is to be noticed that it is hormonally active and able to respond to external stimuli. Thus, as also reported in animal models, after adrenocortical failure or injury, compensatory hormonal function of ectopic rests has been reported [16, 57]. ACTH-mediated hyperplasia of accessory nodules could also account for refractory Cushing's syndrome, replacing adrenal hormonal production [58]. On the other hand, adrenal insufficiency can follow ectopic tissue excision, if this was the only functional adrenal tissue of the patient [10].

All but one (the ectopic adrenocortical carcinoma) currently reported case was clinically silent and incidentally found. Nevertheless, tumors arising from adrenal rests are on record, often benign and non-functioning. In a few cases, ectopic tissue may be directly responsible for Conn's syndrome [59] or ACTH-independent Cushing 's syndrome, due to adenomas $[27,28,39,60,61]$ and exceptionally to carcinomas [32, 62, 63]. Indeed, adenoma is not easily differentiated from normal ectopic tissue, except for an aberrant hormonal production or a large size. Carcinomas are conversely more easily recognizable, based on the Weiss score parameters, as observed in the single malignant case of our series. Other neoplasms of gonadal origin including steroid producing tumors [44, 64-66] have a gross and microscopic resemblance to adrenocortical tumors, determining differential diagnosis problems from overgrown adrenal rests, although the location of gonadal neoplasms is intraparenchymal, while adrenal rests generally occur in the periphery of the gonad [67]. In addition, in the rete testis of $\mathrm{CAH}$ patients, adrenal rests can expand in up to $40 \%$ of cases leading to the so called testicular adrenal rest tumor (TART), that can cause infertility because of compressive/obstructive events $[68,69]$. Such TART nodules are functionally and histologically similar to adrenocortical tissue, and may result from ectopic adrenal cell proliferation or from a totipotent embryonic cell type in the testis [5].

In conclusion, the actual prevalence of ectopic adrenocortical rests in the adult population is probably much higher than reported, but the low clinical relevance and the small size of ectopic nodules cause that most of them are not recognized. Awareness of the occurrence of ectopic adrenal tissue is important because of hyperplasia and even neoplastic transformation of such rests in patients with symptoms caused by hypersecretion of adrenocortical hormones, which can well be ectopically produced. In addition, ectopic adrenal tissue must be differentiated from urogenital tumors, in particular its mimickers, such as renal cell carcinoma and Sertoli Leydig cell tumor, that also partially share the immunophenotypic markers of the adrenal cortex (Melan-A, SF-1, inhibin). Indeed, misinterpretation of ectopic adrenal tissue is unlikely, and morphology and appropriate immunohistochemistry are adequate for addressing a correct diagnosis in most cases.

Author Contribution Conceptualization: De Rosa Giovanni, Volante Marco, Papotti Mauro; Data collection and analysis: Falco Enrico Costantino, Daniele Lorenzo, Metovic Jasna, Bollito Enrico, De Rosa Giovanni, Volante Marco, Papotti Mauro; Writing—original draft preparation: Falco Enrico Costantino; Writing-review and editing: Papotti Mauro, Volante Marco, De Rosa Giovanni; Supervision: Papotti Mauro. All authors edited, reviewed and approved the manuscript.

Funding Open access funding provided by Università degli Studi di Torino within the CRUI-CARE Agreement.

Availability of Data and Material The datasets generated and/or analyzed during the current study are not publicly available due to privacy reasons but are available from the corresponding author on reasonable request.

\section{Declarations}

Ethics Approval The study was conducted in accordance with The Code of Ethics of the World Medical Association (Declaration of Helsinki) and was approved by the Institutional Review Board of the San Luigi Hospital (Protocol AMPRECCO, No. 128/2010).

Conflict of Interest The authors declare no competing interests.

Open Access This article is licensed under a Creative Commons Attribution 4.0 International License, which permits use, sharing, adaptation, distribution and reproduction in any medium or format, as long as you give appropriate credit to the original author(s) and the source, provide a link to the Creative Commons licence, and indicate if changes were made. The images or other third party material in this article are included in the article's Creative Commons licence, unless indicated otherwise in a credit line to the material. If material is not included in the article's Creative Commons licence and your intended use is not permitted by statutory regulation or exceeds the permitted use, you will need to obtain permission directly from the copyright holder. To view a copy of this licence, visit http://creativecommons.org/licenses/by/4.0/. 


\section{References}

1. Xing Y, Lerario AM, Rainey W, Hammer GD (2015) Development of adrenal cortex zonation. Endocrinol Metab Clin North Am 44:243-274. https://doi.org/10.1016/j.ecl.2015.02.001

2. Mills SE (2019) Histology for pathologists, 5th edn. Wolters Kluwer Health, Baltimore

3. Moore KL, Persaud TVN, Torchia MG (2020) The developing human: clinically oriented embryology, 11th edn. Elsevier, Edinburgh

4. Mitty HA (1988) Embryology, anatomy, and anomalies of the adrenal gland. Semin Roentgenol 23:271-279. https://doi.org/10. 1016/s0037-198x(88)80037-3

5. Lack EE (2007) Tumors of the adrenal glands and extraadrenal paraganglia. AFIP Atlas of Tumor Pathology, 4th series. American Registry of Pathology in collaboration with the Armed Forces Institute of Pathology, Washington, D.C.

6. Gutowski WT, Gray G Jr (1979) Ectopic adrenal in inguinal hernia sacs. J Urol 121:353-354. https://doi.org/10.1016/s0022-5347(17) 56783-X

7. El Demellawy D, Nasr A, Samkari A, Pastolero P, Alowami S (2009) Aberrant adrenocortical tissue in hernia sac occurring in an adult: case report and review of the literature. Hernia 13:659-662. https://doi.org/10.1007/s10029-009-0501-6

8. Iyengar V, Pittman DM (2007) Ectopic adrenal gland tissue in inguinal hernia sac. Ann Diagn Pathol 11:291-292. https://doi. org/10.1016/j.anndiagpath.2006.08.001

9. Mendez R, Tellado MG, Somoza I, Liras J, Sanchez-Abuin A, Pais E, et al. (2006) Ectopic adrenal tissue in the spermatic cord in pediatric patients: surgical implications. Int Braz J Urol 32:202-207; discussion 207. https://doi.org/10.1590/s167755382006000200013

10. Senescende L, Bitolog PL, Auberger E, Zarzavadjian Le Bian A, Cesaretti M (2016) Adrenal ectopy of adult groin region: a systematic review of an unexpected anatomopathologic diagnosis. Hernia 20:879-885. https://doi.org/10.1007/s10029-016-1535-1

11. Labarrere CA, Caccamo D, Telenta M, Althabe O, Gutman R (1984) A nodule of adrenocortical tissue within a human placenta: light microscopic and immunocytochemical findings. Placenta 5:139-143. https://doi.org/10.1016/s0143-4004(84)80057-0

12. Armin A, Castelli M (1984) Congenital adrenal tissue in the lung with adrenal cytomegaly. Case report and review of the literature. Am J Clin Pathol 82:225-228. https://doi.org/10.1093/ajcp/82.2. 225

13. Wiener MF, Dallgaard SA (1959) Intracranial adrenal gland; a case report. AMA Arch Pathol 67:228-233.

14. Schechter DC (1968) Aberrant adrenal tissue. Ann Surg 167:421426. https://doi.org/10.1097/00000658-196803000-00017

15. Anderson JR, Ross AH (1980) Ectopic adrenal tissue in adults. Postgrad Med J 56:806-808. https://doi.org/10.1136/pgmj.56.661. 806

16. Falls JL (1955) Accessory adrenal cortex in the broad ligament: incidence and functional significance. Cancer 8:143-150. https:// doi.org/10.1002/1097-0142(1955)8:1

17. Johnson DN, Sadow PM (2018) Exploration of BRAFV600E as a diagnostic adjuvant in the non-invasive follicular thyroid neoplasm with papillary-like nuclear features (NIFTP). Hum Pathol 82:32-38. https://doi.org/10.1016/j.humpath.2018.06.033

18. Seidenwurm D, Smathers RL, Kan P, Hoffman A (1985) Intratesticular adrenal rests diagnosed by ultrasound. Radiology 155:479481. https://doi.org/10.1148/radiology.155.2.3885314

19. Mares AJ, Shkolnik A, Sacks M, Feuchtwanger MM (1980) Aberrant (ectopic) adrenocortical tissue along the spermatic cord. J Pediatr Surg 15:289-292. https://doi.org/10.1016/s00223468(80)80139-4
20. Ozel SK, Kazez A, Akpolat N (2007) Presence of ectopic adrenocortical tissues in inguinoscrotal region suggests an association with undescended testis. Pediatr Surg Int 23:171-175. https://doi. org/10.1007/s00383-006-1826-1.

21. Mari M, Cagnazzi E, Bollito E, Bellina M (2004) Ectopic adrenal cortex tissue in the spermatic cord in association with testicular cancer. Urol Int 73:191-192. https://doi.org/10.1159/000079705

22. Gualtieri T, Segal AD (1949) Report of a case of adrenal-type tumor of the spermatic cord; a review of aberrant adrenal tissues. J Urol 61:949-955. https://doi.org/10.1016/s0022-5347(17)69167-5

23. Janovski NA (1966) Choristoma of heterotopic adrenal tissue in mesosalpinx. Obstet Gynecol 28:380-382

24. Morimoto Y, Hiwada K, Nanahoshi M, Yano S, Kumagai A, Yamamura Y, et al. (1971) Cushing's syndrome caused by malignant tumor in the scrotum: clinical, pathologic and biochemical studies. J Clin Endocrinol Metab 32:201-210. https://doi.org/10. 1210/jcem-32-2-201

25. Lodeville D, Zaroli A, Lampertico P (1981) Adenomatoid tumor of the male genital tract: report of three cases, one associated with adrenal cortical rest. Pathologica 73:629-637.

26. Czaplicki M, Bablok L, Kuzaka B, Janczewski Z (1985) Heterotopic adrenal tissue. Int Urol Nephrol 17:177-181. https://doi.org/ 10.1007/BF02082491

27. van Ingen G, Schoemaker J, Baak JP (1991) A testosteroneproducing tumour in the mesovarium. Pathol Res Pract 187:362370; discussion 370-362. https://doi.org/10.1016/S0344-0338(11) 80807-1

28. Sasano H, Sato S, Yajima A, Akama J, Nagura H (1997) Adrenal rest tumor of the broad ligament: case report with immunohistochemical study of steroidogenic enzymes. Pathol Int 47:493-496. https://doi.org/10.1111/j.1440-1827.1997.tb04529.x

29. Ventura L, Leocata P, Hind A, Greco I, Ventura T (1998) Ectopic adrenal tissue in the spermatic cord. Case report and review of the literature. Arch Ital Urol Androl 70:15-18

30. Usta U, Türkmen, E, Aydin, NE (2006) Adrenal Ectopia Within the Wall of an Ovarian Serous Cystadenoma. Balkan Medical Journal 23:95-98

31. Ors F, Lev-Toaff A, O'Kane P, Qazi N, Bergin D (2007) Paraovarian adrenal rest with MRI features characteristic of an adrenal adenoma. Br J Radiol 80:205-208. https://doi.org/10.1259/bjr/ 52038548

32. Jain SH, Sadow PM, Nose V, Dluhy RG (2008) A patient with ectopic cortisol production derived from malignant testicular masses. Nat Clin Pract Endocrinol Metab 4:695-700. https://doi. org/10.1038/ncpendmet0985

33. Yasar L, Ekin M, Kaya C, and Ozkan Y (2012) A Rare Case of Ectopic Adrenal Tissue in the Left Ovary in a Patient with a Granulosa-Cell Tumor of the Right Ovary. Journal of Gynecologic Surgery 28:220-222. https://doi.org/10.1089/gyn.2011.0055

34. Rabie ME, Shah MT, Jamil S, Al-Shraim MM (2013) Adrenal rests associated with ectopic testis in an adult: Clinical significance. Urol Ann 5:302-304. https://doi.org/10.4103/0974-7796. 120307

35. Zhong H, Xu B, Popiolek DA (2013) Growth patterns of placental and paraovarian adrenocortical heterotopias are different. Case Rep Pathol 2013:205692. https://doi.org/10.1155/2013/205692

36. Mullhaupt G, Mordasini L, Gramann T, Ertel V, Schmid HP, Abt D (2014) Ectopic Adrenocortical Tissue in the Spermatic Cord in a 44-Year-old Man. Urol Case Rep 2:169-170. https://doi.org/10. 1016/j.eucr.2014.05.009

37. Floyd MS Jr, Itam S, Nasir N, Weerasinghe SM, Irwin PP, Maddineni SB (2014) Concomitant testicular seminoma and ectopic adrenal tissue of the cord in a 45-year-old male. Can Urol Assoc J 8:E176-178. https://doi.org/10.5489/cuaj.1584

38. Takeuchi M, Okuya, K, Kato, R, Miyao N and Konishi Y (2014) Aberrant Adrenocortical Tissue Associated with Resected Lipoma 
of Spermatic Cord in an Adult. Open Journal of Urology 4:151154. https://doi.org/10.4236/oju.2014.412026

39. Kasajima A, Nakamura Y, Adachi Y, Takahashi Y, Fujishima F, Chiba Y, et al. (2014) Oncocytic adrenocortical neoplasm arising from adrenal rest in the broad ligament of the uterus. Pathol Int 64:183-188. https://doi.org/10.1111/pin.12154

40. Niveditha SR, Manjula, CP, Sudarshan Babu KG (2014) Accessory Adrenal Cortical Tissue: An Incidental Finding in Hernial Sac. Journal of Evidence Based Medicine and Healthcare 1:157159. https://doi.org/10.18410/jebmh/2014/26

41. Raman RT, Sree RR, Hemanathan G, Savitri NM, Anuradha S (2014) Adrenal cortex heterotopia in an undescended testis-a case report. J Clin Diagn Res 8:11-12. https://doi.org/10.7860/JCDR/ 2014/8331.4845

42. Sangeeta M, Parthiban, R., and Shiny Vinila BH (2014) Ectopic Adrenal Rests in Testis - A Case Report. International Journal of Basic and Applied Medical Sciences 4:42-44

43. Khandakar B, Dey S, Ray PS, Sarkar R, Bhattacharyya P (2015) Ectopic Paratubal Adrenal Cell Rest Associated with Mucinous Cystadenoma of Ovary. J Clin Diagn Res 9:ED13-14. https://doi. org/10.7860/JCDR/2015/15411.6638

44. Chentli F, Terki N, Azzoug S (2016) Ectopic adrenocortical carcinoma located in the ovary. Eur J Endocrinol 175:17-23. https:// doi.org/10.1530/EJE-16-0224

45. Billone V, Rotolo S, Trapani A, Triolo M, Guarneri M, Calagna G, Di Buono G, Sorce V, Agrusa A, Perino A (2017) Excision of ectopic adrenocortical tissue during laparoscopy for isolated tubal torsion. Giornale Italiano di Ostetricia e Ginecologia 39:40-43. https://doi.org/10.11138/giog/2017.39.1.040

46. KT Chew MA Abu Y Arifuddin NA Mohamed Ismail NAM Nasir F Mohammed et al 2017 Ectopic adrenal tissue associated with borderline mucinous cystadenoma of ovary: a case report with review of the literature Horm Mol Biol Clin Investig $32 \mathrm{https}$ :// doi.org/10.1515/hmbci-2017-0021

47. Kassaby SS, Velilla RE, Shurbaji MS (2017) Adrenal cortical heterotopia in an inguinal hernia sac of an adult: A case report and literature review. Human Pathology: Case Reports 8:13-15. https://doi.org/10.1016/j.ehpc.2016.08.007

48. Sahin C, Taylan E, Akdemir A, Zekioglu O, Seyidova P, Ergenoglu AM (2017) Ovarian serous cystadenoma with ectopic adrenal tissue in a 65-year-old patient: A case report. Int J Surg Case Rep 33:89-91. https://doi.org/10.1016/j.ijscr.2017.02.045

49. Tingi E, Ogah J (2018) Ectopic adrenal rest cells of the fallopian tube: a case report and review of the literature. J Obstet Gynaecol 38:578-579. https://doi.org/10.1080/01443615.2017.1379063

50. Alimoradi M, El-Helou E, Sabra H, Azaki R, Khairallah M, Matta $\mathrm{N}$ (2020) Ectopic adrenal gland in an adult inguinal hernial sac: A case report. Int J Surg Case Rep 72:66-68. https://doi.org/10. 1016/j.ijscr.2020.05.047

51. Hollinshead WH (1982) Anatomy for surgeons, 3rd edn. Harper $\&$ Row, London.

52. Pappis CH, Argianas SA, Bousgas D, Athanasiades E (1988) Unsuspected urological anomalies in asymptomatic cryptorchid boys. Pediatr Radiol 18:51-53. https://doi.org/10.1007/BF02395760

53. Sullivan JG, Gohel M, Kinder RB (2005) Ectopic adrenocortical tissue found at groin exploration in children: incidence in relation to diagnosis, age and sex. BJU Int 95:407-410. https://doi.org/10. 1111/j.1464-410X.2005.05310.x

54. Vaos G, Zavras N, Boukouvalea I (2006) Ectopic adrenocortical tissue along the inguinoscrotal path of children. Int Surg 91:125-128
55. Pogorelic Z, Rikalo M, Jukic M, Katic J, Juric I, Furlan D, et al. (2017) Modified Marcy repair for indirect inguinal hernia in children: a 24-year single-center experience of 6826 pediatric patients. Surg Today 47:108-113. https://doi.org/10.1007/ s00595-016-1352-2

56. Niedzielski JK, Oszukowska E, Slowikowska-Hilczer J (2016) Undescended testis - current trends and guidelines: a review of the literature. Arch Med Sci 12:667-677. https://doi.org/10.5114/ aoms.2016.59940

57. Mori H, Matsumoto K (1974) Constant occurrence of adrenocortical tissue in the juvenile rabbit ovary. Am J Anat 141:73-90. https://doi.org/10.1002/aja.1001410105

58. Nieman LK, Biller BM, Findling JW, Murad MH, Newell-Price J, Savage MO, et al. (2015) Treatment of Cushing's Syndrome: An Endocrine Society Clinical Practice Guideline. J Clin Endocrinol Metab 100:2807-2831. https://doi.org/10.1210/jc.2015-1818

59. Arnold J, Mitchell A (1989) Conn's syndrome due to an ectopic adrenal adenoma. Postgrad Med J 65:847-848. https://doi.org/10. 1136/pgmj.65.769.847

60. Mazza E, Papotti M, Durando R, Robecchi A, Camanni F (1995) Ectopic aldosteronoma associated to another adrenocortical adenoma in the adrenal gland of the same side. J Endocrinol Invest 18:809-812. https://doi.org/10.1007/BF03349816

61. Dotto RS, Marx G, Bastos M, Machado JL, Glufke V, de Oliveira Freitas DM (2019) A rare case of virilizing adult ectopic adrenal tumor. Urol Case Rep 27:100907. https://doi.org/10.1016/j.eucr. 2019.100907

62. Boisbeunet $\mathrm{P}$ (1955) [Urologic diagnosis of a metastasizing malignant tumor of probable adreno-cortical origin]. J Urol Medicale Chir 61:431-433

63. Yokoyama H, Adachi T, Tsubouchi K, Tanaka M, Sasano H (2013) Non-functioning adrenocortical carcinoma arising in an adrenal rest: immunohistochemical study of an adult patient. Tohoku J Exp Med 229:267-270. https://doi.org/10.1620/tjem.229.267

64. Goldblum JR, Lamps LW, McKenney JK, Myers JL, Ackerman LV (2017) Rosai and Ackerman's surgical pathology. Eleventh ed. Elsevier, Philadelphia.

65. Marieb NJ, Spangler S, Kashgarian M, Heimann A, Schwartz ML, Schwartz PE (1983) Cushing's syndrome secondary to ectopic cortisol production by an ovarian carcinoma. J Clin Endocrinol Metab 57:737-740. https://doi.org/10.1210/jcem-57-4-737

66. Hayes MC, Scully RE (1987) Ovarian steroid cell tumors (not otherwise specified). A clinicopathological analysis of 63 cases. Am J Surg Pathol 11:835-845. https://doi.org/10.1097/00000478198711000-00002

67. Young R, Scully, R (2008) Sex Cord-Stromal, Steroid Cell, and Germ Cell Tumors of the Ovary. In: Glob libr women's med. https://doi.org/10.3843/GLOWM.10249

68. New MI (2004) An update of congenital adrenal hyperplasia. Ann N Y Acad Sci 1038:14-43. https://doi.org/10.1196/annals.1315. 009

69. Engels M, Span PN, van Herwaarden AE, Sweep F, Stikkelbroeck N, Claahsen-van der Grinten HL (2019) Testicular Adrenal Rest Tumors: Current Insights on Prevalence, Characteristics, Origin, and Treatment. Endocr Rev 40:973-987. https://doi.org/10.1210/ er.2018-00258

Publisher's Note Springer Nature remains neutral with regard to jurisdictional claims in published maps and institutional affiliations. 